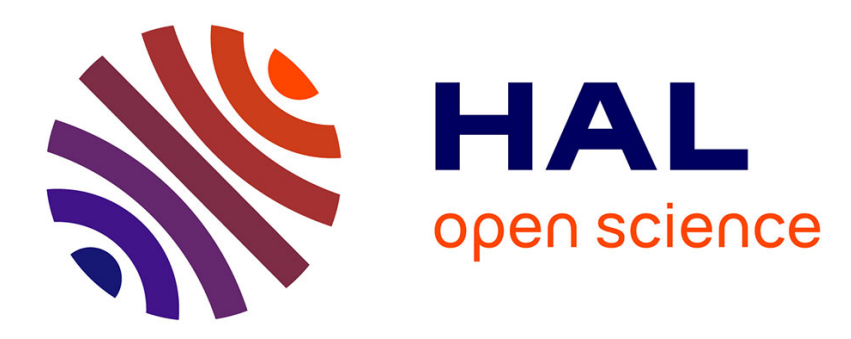

\title{
Mild and efficient rhodium-catalyzed deoxygenation of ketones to alkanes
}

Gilles Argouarch

\section{To cite this version:}

Gilles Argouarch. Mild and efficient rhodium-catalyzed deoxygenation of ketones to alkanes. New Journal of Chemistry, 2019, 43 (28), pp.11041-11044. 10.1039/c9nj02954k . hal-02278412

HAL Id: hal-02278412

https://hal-univ-rennes1.archives-ouvertes.fr/hal-02278412

Submitted on 23 Sep 2019

HAL is a multi-disciplinary open access archive for the deposit and dissemination of scientific research documents, whether they are published or not. The documents may come from teaching and research institutions in France or abroad, or from public or private research centers.
L'archive ouverte pluridisciplinaire HAL, est destinée au dépôt et à la diffusion de documents scientifiques de niveau recherche, publiés ou non, émanant des établissements d'enseignement et de recherche français ou étrangers, des laboratoires publics ou privés. 


\title{
Mild and efficient rhodium-catalyzed deoxygenation of ketones to alkanes
}

\author{
Gilles Argouarch*
}

\begin{abstract}
A new and simple method for the deoxygenation of ketones to alkanes is presented. Most substrates are reduced under mild conditions by triethylsilane in the presence of catalytic amounts of $\left[\mathrm{Rh}(\mu-\mathrm{Cl})(\mathrm{CO})_{2}\right]_{2}$. This system selectively provides the methylene hydrocarbons in good to excellent yields starting from acetophenones and diaryl ketones. A rapid examination of the reaction pathway suggests that the ketone is first converted in alcohol which then undergoes hydrogenolysis to give the alkane.
\end{abstract}

Over a century ago the reactions of Clemmensen and WolffKishner opened the way to the transformation of ketones to alkanes through carbonyl-to-methylene complete reduction. Unfortunately, these methodologies were suffering from harsh reaction conditions making them incompatible to a large panel of functional groups. In the search for mild and less toxic reactions that reduce ketones into methylenes, later advances were made by the use of metal-hydride reagents or silanes with Lewis or Brønsted acids, even if some limitations remained regarding chemoselectivity. ${ }^{1}$

More recently, deoxygenation of ketones was also accomplished by transition-metal catalysis. In this field, a limited number of catalytic systems based on the use of molecular hydrogen as the reducing agent were reported and proved to be enough selective to overcome the hydrogenation competitive pathway in the course of the reaction. ${ }^{2}$ Even more rare are the metal-based catalysts employing a hydrosilane as the hydride source that allowed this deoxygenation reaction, in place of the more classical hydrosilylation reduction. Palladium species were first introduced in 2008 with the combination $\left[\mathrm{PdCl}_{2}\right] / \mathrm{HSiEt}_{3},{ }^{3}$ and subsequent improvements were made by using $\left[\mathrm{Pd}(\mathrm{OAc})_{2}\right],{ }^{4}\left[\mathrm{PdCl}_{2}\right],{ }^{5}$ or even $\mathrm{Pd} / \mathrm{C}^{6}$ in the presence of polymethylhydrosiloxane (PMHS). Another method relying on the system $\left[\mathrm{FeCl}_{3}\right] / \mathrm{PMHS}$ and which necessitated a microwave irradiation was also reported. ${ }^{7}$ High-valent rhenium and

Univ Rennes, CNRS, ISCR - UMR 6226, F-35000 Rennes, France.

E-mail: gilles.argouarch@univ-rennes1.fr

+ Electronic Supplementary Information (ESI) available: experimental details and analytical data of the products. See DOI: 10.1039/x0xx00000x molybdenum complexes were used as well and the deoxygenation of ketones was achieved by $\mathrm{PhSiH}_{3}$ with catalytic amounts of $\left[\mathrm{MoCl}_{2} \mathrm{O}_{2}\left(\mathrm{H}_{2} \mathrm{O}\right)_{2}\right],{ }^{8}$ and $\left[\mathrm{ReOCl}_{3}\left(\mathrm{SMe}_{2}\right)\left(\mathrm{OPPh}_{3}\right)\right]$ or $\left[\mathrm{ReOCl}_{3}\left(\mathrm{PPh}_{3}\right)_{2}\right] .{ }^{9}$ Finally, an oxazolinylborate-coordinated rhodium silylene, highly active in the deoxygenation of esters to ethers, was briefly tested on ketones but led to the formation of alkanes with modest yields. ${ }^{10}$

Herein we disclose that the commercially available rhodium(I) dimeric complex $\left[\mathrm{Rh}(\mu-\mathrm{Cl})(\mathrm{CO})_{2}\right]_{2}$ constitutes a simple and efficient catalyst for the mild deoxygenation of aromatic ketones under hydrosilylation conditions. Although this wellknown neutral complex has been used previously in very important catalytic transformations, ${ }^{11}$ to the best of our knowledge, this represents its first application in the reduction of carbonyl compounds.

Optimization experiments were carried out with 4acetylbiphenyl (1a) as the model substrate (Scheme 1). Various solvents and silanes were tested with a catalyst loading of 1 mol\%. After reaction and acidic hydrolysis, the conversion of $1 \mathbf{a}$ and the proportions of alcohol $\mathbf{2 a}$ to hydrocarbon $3 \mathbf{3 a}$ were determined by ${ }^{1} \mathrm{H}$ NMR (Table 1 ).
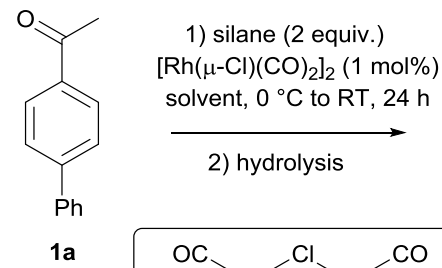

2) hydrolysis

$$
\begin{aligned}
& \mathrm{OC}^{\mathrm{OC}}{ }_{\mathrm{Rh}}^{-} \underset{\mathrm{Cl}^{-}}{-\mathrm{Rh}}{ }_{\mathrm{CO}}^{\mathrm{CO}} \\
& {\left[\mathrm{Rh}(\mu-\mathrm{Cl})(\mathrm{CO})_{2}\right]_{2}}
\end{aligned}
$$

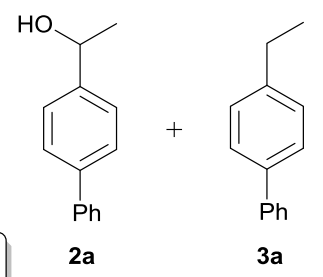

$3 a$
Scheme 1 Reduction of 1a under various conditions.

When the reduction of 1a was carried out with $\mathrm{Ph}_{2} \mathrm{SiH}_{2}$ and $\left[\mathrm{Rh}(\mu-\mathrm{Cl})(\mathrm{CO})_{2}\right]_{2}$, good conversions ranging from $89 \%$ to $95 \%$ were achieved in acetonitrile, toluene, THF, and DCM, and alcohol $\mathbf{2 a}$ was obtained as the major product (Table 1, entries 1-4). At that stage, the deoxygenated product 3a was formed 
only in negligible amounts (1-5\%). By using PMHS in DCM, the reactivity was maintained with an increase in the amount of $\mathbf{3 a}$ corresponding to $8 \%$ of the product (Table 1 , entry 5 ). The more reactive silane $\mathrm{PhSiH}_{3}$ gave full conversion of the ketone and a significant change in the outcome of the reaction which gave $28 \%$ of 3 a versus $72 \%$ of 2 a (Table 1 , entry 6 ). Finally, a switch of the selectivity in favor of the deoxygenation pathway was fully reached with a combination between the $\mathrm{Rh}(\mathrm{I})$ complex and the monohydrosilane $\mathrm{HSiEt}_{3}$ in DCM as 3a was virtually the only product arising from the complete reduction of $1 \mathbf{1 a}$ by this way (Table 1, entry 7). Under these conditions, attempts to decrease the catalyst loading turned out to be detrimental to the conversion of ketone $\mathbf{1}$ a.

Table 1 Optimization experiments of the Rh-catalyzed deoxygenation of 4-acetylbiphenyl (1a)

\begin{tabular}{lllll}
\hline Entry & Silane & Solvent & Conv. (\%) & 2a/3a (\%) \\
\hline 1 & $\mathrm{Ph}_{2} \mathrm{SiH}_{2}$ & MeCN & 89 & $99 / 1$ \\
2 & $\mathrm{Ph}_{2} \mathrm{SiH}_{2}$ & toluene & 94 & $99 / 1$ \\
3 & $\mathrm{Ph}_{2} \mathrm{SiH}_{2}$ & THF & 95 & $95 / 5$ \\
4 & $\mathrm{Ph}_{2} \mathrm{SiH}_{2}$ & DCM & 94 & $99 / 1$ \\
5 & $\mathrm{PMHS}$ & DCM & 96 & $92 / 8$ \\
6 & $\mathrm{PhSiH}_{3}$ & DCM & $>99$ & $72 / 28$ \\
7 & $\mathrm{HSiEt}_{3}$ & DCM & $>99$ & $1 / 99$
\end{tabular}

a Determined by ${ }^{1} \mathrm{H}$ NMR of the crude products.

The optimized reaction conditions were next presented to a variety of substrates (Table 2). Ketones 1a-r were thus treated with $1 \mathrm{~mol} \%$ catalyst and a two-fold amount of $\mathrm{HSiEt}_{3}$ in DCM for one day. Overall, ${ }^{1} \mathrm{H}$ NMR analysis of the crude samples after reaction revealed that no hydrosilylation adduct (alkoxysilane) was present or only in trace amounts. Consequently work-up became useless and the samples could be simply evaporated and subjected to chromatography. For electron-neutral ketones 1a-d, the corresponding arenes 3a-d were formed quantitatively and high isolated yields were obtained for $3 a$ and 3b (Table 2, entries 1-4). The para and ortho isomers of methylacetophenone $\mathbf{1 e}$ and $\mathbf{1 f}$ gave also good rates of formation of products $\mathbf{3 e}$ and $\mathbf{3 f}$ which were isolated in $63 \%$ and $67 \%$ yields, respectively (Table 2, entries 5 and 6). These moderate yields were in part attributable to the low polarity of such compounds making their separation from the by-products of the silane sometimes delicate. This method was also tested on more encumbered substrates such as ketones $\mathbf{1 g - i}$ (Table 2, entries 7-9). Although a complete conversion was observed with $\alpha$-tetralone $(\mathbf{1 g})$ and cyclohexyl phenyl ketone (1h), isobutyrophenone (1i) only produced $78 \%$ of hydrocarbon $\mathbf{3 i}$. Interestingly, this method could also be applied to ferrocene derivatives (Table 2, entries 10-14). With acetylferrocene (1j), an incomplete conversion of $85 \%$ was obtained when $\mathrm{HSiEt}_{3}$ was used as the hydride source but fortunately $\mathrm{PhSiH}_{3}$ and PMHS afforded ethylferrocene (3j) in quantitative form. This contrasts from the results gathered with the model substrate 1a for which $\mathrm{HSiEt}_{3}$ was the most efficient silane to achieve deoxygenation and implies that the selectivity of this protocol is not restricted to one silane but is rather dependent on the two reactants in presence. Similarly, in the case of benzoylferrocene (1k), no reaction occured with $\mathrm{HSiEt}_{3}$ whereas $\mathrm{PhSiH}_{3}$ gave $\mathbf{3 k}$ in $94 \%$ isolated yield.

Table 2 Scope and limitations of the Rh-catalyzed deoxygenation of ketonesa

(1)


19

20<smiles>CC(=O)c1ccc(Cl)cc1</smiles>

$\mathrm{HSiEt}_{3}$<smiles>CCc1ccc(Cl)cc1</smiles>

30<smiles>CC(=O)c1ccc(F)cc1</smiles>

$\mathrm{HSiEt}_{3}$<smiles>CCc1ccc(F)cc1</smiles>

$\mathrm{HSiEt}_{3}$

$$
3 p
$$<smiles>O=C(c1ccccc1)C(F)(F)F</smiles>

$1 q$<smiles>O=C(c1ccccc1)c1ccccc1</smiles>

1<smiles>FC(F)(F)Cc1ccccc1</smiles>

$3 q$
$\mathrm{HSiEt}_{3}$

$3 r$<smiles>c1ccc(Cc2ccccc2)cc1</smiles>

a Typical conditions: ketone $(1 \mathrm{mmol})$, silane $(2 \mathrm{mmol}),[\mathrm{Rh}(\mu-$ $\left.\mathrm{Cl})(\mathrm{CO})_{2}\right]_{2}(1 \mathrm{~mol} \%), \mathrm{DCM}(3 \mathrm{~mL}), 0{ }^{\circ} \mathrm{C}$ to RT, $24 \mathrm{~h}$. b Conversions (\%) determined according to ${ }^{1} \mathrm{H}$ NMR spectroscopy of the crude products, isolated yields (\%) are given into brackets.

In the screening of ketones with significant electronic effects, some limitations were apparent (Table 2, entries 15-21). While methoxy groups on compounds $\mathbf{1 l}$ and $\mathbf{1} \mathbf{m}$ had no effect on the reactions affording alkylated anisoles $\mathbf{3} \mathbf{l}$ and $\mathbf{3 m}$ with good yields, the diethylamino moiety within the electron-rich ketone In completely inhibited the deoxygenation. Likewise, halogenated ketones $\mathbf{1 0}$ and $\mathbf{1}$ p participated well in the reaction but a severe limitation were encountered in the case of the more challenging electron-poor 2,2,2-trifluoroacetophenone (1q) which gave a low conversion of $20 \%$. In addition, as a typical diaryl ketone, benzophenone (1r) was also nicely converted to arene $\mathbf{3 r}$ in $77 \%$ isolated yield (Table 2 , entry 22 ).

The Rh/HSiEt ${ }_{3}$ system was further extended to miscellaneous substrates (Scheme 2). The phenolic ketone 1s was engaged in the reaction, and despite its full consumption, 4-ethylphenol (3s) was isolated only in 45\% yield because triethylsilyl ethers 4 and $\mathbf{5}$ were formed concomitantly. This competition between deoxygenation and O-silylation was not surprising since rhodium complexes are known to catalyze the dehydrogenative silylation of alcohols and phenols with hydrosilanes. ${ }^{12}$

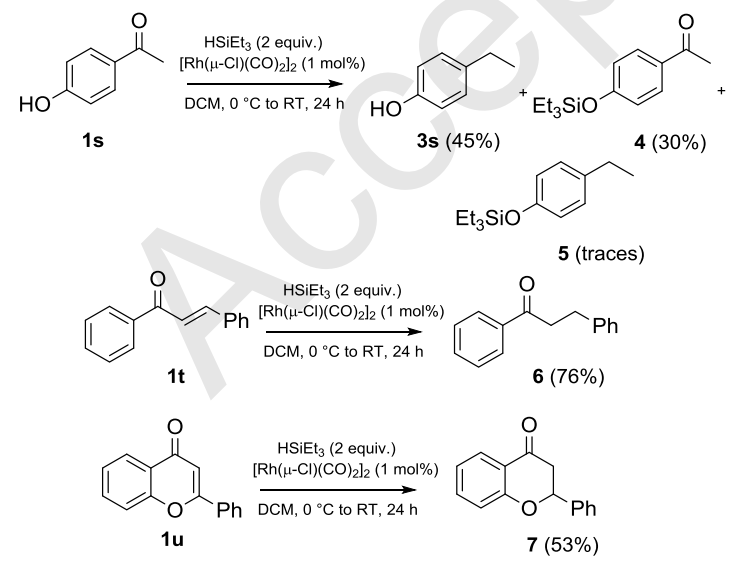

Scheme 2 Rh-catalyzed reduction of compounds 1s-u.

The reaction of the $\alpha, \beta$-unsaturated ketone 1 t went to completion and gave product 6 in good yield (76\%). This was likely the result of a 1,4-hydrosilylation of the starting enone followed by decomposition of the silyl enol ether intermediate, as reported elsewhere with rhodium, ${ }^{13}$ rather than a hydrogenation of the $\mathrm{C}=\mathrm{C}$ bond with $\mathrm{H}_{2}$ arising from silane dehydrodimerization or hydrolysis. ${ }^{14}$ Similarly, flavone $\mathbf{1 u}$ was nicely converted into flavanone 7 which was isolated in 53\% yield.

Some experiments on various aldehydes and aliphatic ketones were also run. After hydrolysis, only alcohols were obtained. For instance, the reduction of 1,3-diphenylacetone (1v) led to the clean formation of 1,3-diphenylpropan-2-ol (2v) (Scheme 3). Keto-esters followed the same trend according to which ethyl phenylglyoxalate (1w) was fully transformed into ethyl mandelate $(\mathbf{2 w})$.

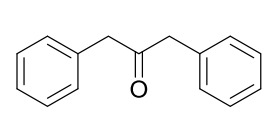

$1 v$

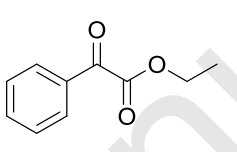

$1 \mathrm{w}$

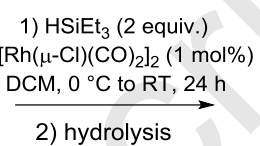

2) hydrolysis

1) $\mathrm{HSiEt}_{3}$ ( 2 equiv.) $\left[\mathrm{Rh}(\mu-\mathrm{Cl})(\mathrm{CO})_{2}\right]_{2}(1 \mathrm{~mol} \%)$
$\mathrm{DCM}, 0^{\circ} \mathrm{C}$ to $\mathrm{RT}, 24 \mathrm{~h}$ 2) hydrolysis

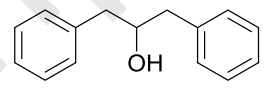

2v

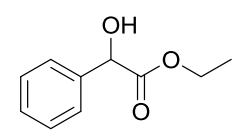

2w
Scheme 3 Rh-catalyzed hydrosilylation of compounds $\mathbf{1 v}$ and $1 \mathbf{w}$.

In the literature, ${ }^{4-9}$ although the mechanistic details of the transition-metal catalyzed deoxygenation of ketones in the presence of silanes are not yet clear, it was established that this reductive process proceeds in two steps, where the ketone is first reduced to an alcohol which in turn undergoes hydrogenolysis to form the alkylated product. To assess this with rhodium, control experiments were conducted (Scheme 4).<smiles>CC(O)c1ccc(-c2ccccc2)cc1</smiles>

$2 a$<smiles>COC(C)c1ccc(-c2ccccc2)cc1</smiles>

8<smiles>COc1ccc(C(C)O)cc1</smiles>

2I<smiles>OC(c1ccccc1)c1ccccc1</smiles>

$2 r$
$\mathrm{HSiEt}_{3}$ (2 equiv.)
$\left[\stackrel{\left.\operatorname{Rh}(\mu-\mathrm{Cl})(\mathrm{CO})_{2}\right]_{2}(1 \mathrm{~mol} \%)}{\longrightarrow}\right.$ $\mathrm{DCM}, 0^{\circ} \mathrm{C}$ to RT, $24 \mathrm{~h}$

3a $(88 \%)$

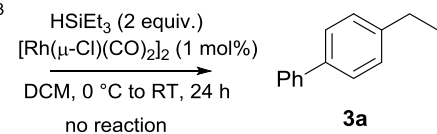

$\mathrm{HSiEt}_{3}$ (2 equiv.) $\left[\mathrm{Rh}(\mu-\mathrm{Cl})(\mathrm{CO})_{2}\right]_{2}(1 \mathrm{~mol} \%)$ DCM, $0{ }^{\circ} \mathrm{C}$ to RT, $24 \mathrm{~h}$

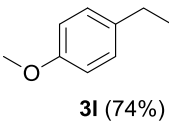

$\mathrm{HSiEt}_{3}$ (2 equiv.) $\left[\mathrm{Rh}(\mu-\mathrm{Cl})(\mathrm{CO})_{2}\right]_{2}(1 \mathrm{~mol} \%)$ DCM, $0{ }^{\circ} \mathrm{C}$ to RT, $24 \mathrm{~h}$

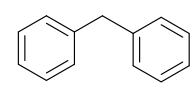

$3 r(70 \%)$
Scheme 4 Control experiments on the deoxygenation process and generalization of the Rh-catalyzed hydrogenolysis of benzylic alcohols. 
When the benzylic alcohol $\mathbf{2 a}$ was engaged in the deoxygenation reaction, it was successfully converted to arene 3a which was isolated in $88 \%$ yield. On the contrary, no reaction occured starting from the trimethylsilyl ether $\mathbf{8}$. Thus, it can be postulated that the mechanism of this reaction also involves the release of an alcohol and that this latter probably doesn't originate from a hydrosilylation adduct of type $\mathbf{8}$ that remained inert under the reaction conditions.

Finally, the applicability of the hydrogenolysis of benzylic alcohols by the system $\left[\mathrm{Rh}(\mu-\mathrm{Cl})(\mathrm{CO})_{2}\right]_{2} / \mathrm{HSiEt}_{3}$ was briefly extended (Scheme 4). Besides the model compound $\mathbf{2 a}$, full conversion of alcohols $\mathbf{2} \mathbf{I}$ and $\mathbf{2} \mathbf{r}$ also happened, and products $\mathbf{3} \mathbf{I}$ and $\mathbf{3 r}$ were isolated in $74 \%$ and $70 \%$ yields, respectively.

In conclusion, this work has provided an original and straightforward method for the deoxygenation of ketones and has drawn light on the catalytic properties of the readily available rhodium complex $\left[\mathrm{Rh}(\mu-\mathrm{Cl})(\mathrm{CO})_{2}\right]_{2}$ in the reduction of carbonyl compounds. Herein, this precatalyst was able without the aid of any additives to convert the $\mathrm{C}=\mathrm{O}$ group of a series of ketones into methylenes in the presence of weak reducing agents such as $\mathrm{HSiEt}_{3}$. This system operating under mild conditions and in non protic media was also efficient in the hydrogenolysis of benzylic alcohols. Other interesting uses of this catalyst in reductive reactions will be reported in due course.

\section{Conflicts of interest}

There are no conflicts to declare.

\section{Acknowledgements}

Université de Rennes 1 and CNRS are acknowledged for financial supports.

\section{Notes and references}

1 a) N. Sakai, K. Nagasawa, R. Ikeda, Y. Nakaike and T. Konakahara, Tetrahedron Lett., 2011, 52, 3133; b) J. Choi and Y. Kang, Bull. Korean Chem. Soc., 2005, 26, 343; c) T. Miyai, M. Ueba and A. Baba, Synlett, 1999, 182.

2 Representative examples: a) G. La Sorella, L. Sperni, P. Canton, L. Coletti, F. Fabris, G. Strukul and A. Scarso, J. Org. Chem., 2018, 83, 7438; b) C. Schäfer, C. J. Ellstrom, H. Cho and B. Török, Green Chem., 2017, 19, 1230; c) D. M. Grainger, A. Zanotti-Gerosa, K. P. Cole, D. Mitchell, S. A. May, P. M. Pollock and J. R. Calvin, ChemCatChem, 2013, 5, 1205; d) L. Zhou, Z. Liu, Y. Liu, Y. Zhang and J. Wang, Tetrahedron, 2013, 69, 6083 e) M. Cano, A. M. Benito, W. K. Maser and E. P. Urriolabeitia, New J. Chem., 2013, 37, 1968; f) J. Hermannsdörfer and R. Kempe, Chem. Eur. J., 2011, 17, 8071; g) C. Van Doorslaer, J. Wahlen, P. G. N. Mertens, B. Thijs, P. Nockemann, K. Binnemans and D. E. De Vos, ChemSusChem, 2008, 1, 997.

3 M. Mirza-Aghayan, R. Boukherroub and M. Rahimifard, J. Organomet. Chem., 2008, 693, 3567.

4 R. J. Rahaim Jr. and R. E. Maleczka Jr., Org. Lett., 2011, 13, 584.

5 a) H. Wang, L. Li, X.-F. Bai, J.-Y. Shang, K.-F. Yang and L.-W. Xu, Adv. Synth. Catal., 2013, 355, 341; b) H. Wang, L. Li, X.-F. Bai, W.-H. Deng, Z.-J. Zheng, K.-F. Yang and L.-W. Xu, Green Chem., 2013, 15, 2349.
6 A. Volkov, K. P. J. Gustafson, C.-W. Tai, O. Verho, J.-E. Bäckvall and H. Adolfsson, Angew. Chem. Int. Ed., 2015, 54, 5122.

7 C. Dal Zotto, D. Virieux and J.-M. Campagne, Synlett, 2009, 276.

8 S. C. A. Sousa, T. A. Fernandes and A. C. Fernandes, Eur. J. Org. Chem., 2016, 3109.

9 T. A. Fernandes, J. R. Bernardo and A. C. Fernandes, ChemCatChem, 2015, 7, 1177.

10 S. Xu, J. S. Boschen, A. Biswas, T. Kobayashi, M. Pruski, T. L. Windus and A. D. Sadow, Dalton Trans., 2015, 44, 15897.

11 For recent examples see: a) W. Song, N. Zheng, M. Li, K. Ullah and Y. Zheng, Adv. Synth. Catal., 2018, 360, 2429; b) N. Zheng, W. Song, T. Zhang, M. Li, Y. Zheng and L. Chen, J. Org. Chem., 2018, 83, 6210; c) Y. Kawaguchi, K. Yabushita and C. Mukai, Angew. Chem. Int. Ed., 2018, 57, 4707; d) Y. Kawaguchi, A. Nagata, K. Kurokawa, H. Yokosawa and C. Mukai, Chem. Eur. J., 2018, 24, 6538; e) C.-H. Liu and Z.-X. Yu, Angew. Chem. Int. Ed., 2017, 56, 8667; f) X. Li, J. Pan, H. Wu and N. Jiao, Chem. Sci., 2017, 8, 6266; g) Y. Liao, Q. Lu, G. Chen, Y. Yu, C. Li and X. Huang, ACS Catal., 2017, 7, 7529.

12 a) I. Ojima, T. Kogure, M. Nihonyanagi, H. Kono and S. Inaba, Chem. Lett., 1973, 501; b) R. J. P. Corriu and J. J. E. Moreau, J. Organomet. Chem., 1976, 120, 337; c) M. P. Doyle, K. G. High, V. Bagheri, R. J. Pieters, P. J. Lewis and M. M. Pearson, J. Org. Chem., 1990, 55, 6082.

13 Representative examples: a) G. Onodera, R. Hachisuka, T. Noguchi, H. Miura, T. Hashimoto and R. Takeuchi, Tetrahedron Lett., 2014, 55, 310; b) H. Sato, T. Fujihara, Y. Obora, M. Tokunaga, J. Kiyosu and Y. Tsuji, Chem. Commun., 2007, 269; c) L. V. Dinh and J. A. Gladysz, New J. Chem., 2005, 29, 173; d) G. Rivera and R. H. Crabtree, J. Mol. Catal. A:Chem., 2004, 222, 59.

14 Several attempts to reduce styrene derivatives with the present system were unsuccessful. 